\title{
LEVE
}

\section{Landsforeningen for etterlatte ved selvmord}

Ved Terese Grøm

Rom for egen sorg og stille samvar. Det var tanken bak gudstjenestene som ble holdt for etterlatte ved selvmord i Oslo og Bergen denne høsten. Og et nytt fylkeslag er etablert, denne gang i Østfold.

\section{Kirken som fellesrom \\ A llehelgensdag i 0 slo}

A ll ehelgensdag, søndag 3. november, arrangerte K irkens SOS i O slo messe for etterlatte ved selvmord i Tøyenkirken. I tett samarbeid med LEV Es sekretariat og fylkeslagi 0 slo la de opp til en minnestund hvor samvær, fellesopplevelse og rom for egen sorg var i fokus. Steinar Lindvig, prest og ansatt i Kirkens SOS i O slo, var én av initiativtakerne til gudstjenesten.

- Vi har hatt et stort ønske om å få gjøre noe spesielt for dem som har mistet en som stod dem nær ved selvmord. LEVE sitter med de nærmeste menneskelige erfaringene på dette området, så det var naturlig for oss å invitere foreningen til samarbeid, sier Steinar Lindvig.

- Som arrangør ville vi gjerne lage en god form og et innhold som kunne treffe dem som kom. A finne et ståsted i det som er vanskelig, hvor man kan møte andre som er i samme situasjon, er noe av det viktigste vi ville formidle på en slik dag, sier Lindvig.

\section{G udstjeneste i B ergen}

LEVE H ordaland ble tidligere i år kontaktet av Bergen lokallag av Landsforbun- det mot stoffmisbruk. De ville gjerne samarbeide med LEVE om en minnestund for etterlatte ved selvmord og pårørende ved stoffmisbruk. Dermed var de sammen om å innby til gudstjeneste i Korskirken i Bergen, søndag 27. oktober, ved biskop O le D. H agesæther.

- Vi la opp til åpen kirke denne søndagen. Det betyr at vi under gudstjenesten satte av tid til at man kunne gå litt rundt i kirkerommet, tenne lys, få vel signelse og forbønn. Eller bare sitte stille og være til stede, sier Jarle M ortensen, leder av LEV E $\mathrm{H}$ ordaland. Representanter fra LEV E $\mathrm{H}$ ordaland deltok både i musikkfremførelse og tekstlesing.

- Den røde tråden for kvelden var håpet. Vi ville gjennom en minnemarkering understreke hvor viktig håpet er $\mathrm{i}$ et menneskes liv når alt er mørkt og vondt, sier M ortensen.

\section{LEVE er snart landsdekkende}

Til slutt er vi glade for å kunne informere om den første dagskonferansen LEVE holdt i $\varnothing$ stfold. Det skjedde 9. november på ærverdige Torderød gård på J eløya ved M oss. Finn Borgersen, leder ved LEVE, var dagens ordstyrer.

\section{Hovedarbeidsområder:}

\section{Omsorg}

- å sikre aktiv hjelp og støtte til familier, pårørende og evt. andre berørte som mister noen av sine nærmeste ved selvmord. Et offentlig oppfølgingstil bud er også viktig.

\section{Informasjon}

- å drive opplysningsvirksomhet og spre informasjon om selvmord og etterlattes situasjon i befolkningen og blant hel sepersonell.

\section{Forskning}

- å arbeide aktivt for å skaffe midler til forskningsformål, for å forebygge selvmord og bedre omsorgen for dem som er rammet.

LEV E, Postboks 27 Smestad, 03090 slo

Telefon/faks.: 22523005

E-post: leve.no@online.no

Internettadresse: www.levenorge.no

K to.nr.: 05333982147

- D e vakre lokal ene satte gode rammer for arrangementet, spesielt for minnemarkeringen som ble holdt av A nn Kristin Rangøy, prest i M oss menighet. $A \vee$ del takerne var de etterlatte klart i flertall, men representanter for både etterlatte og fagpersoner viste interesse for å være med $\mathrm{i}$ interimstyret. Interimstyret vil bli satt innen utgangen av år 2002, sier Finn Borgersen.

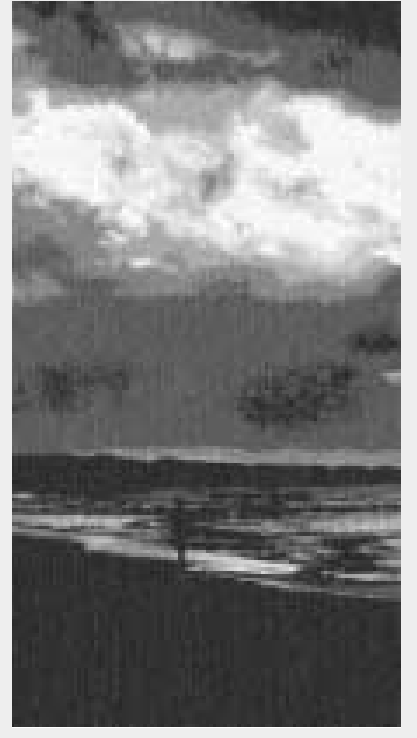

\section{$D E N \quad D A G \quad K J E M \quad A L D R I$}

Den dag kjem aldri at eg deg gløymer, for um eg søver, eg um deg drøymer. U m nott og dag er du like nær, og best eg ser deg når myrkt det er.

Du leikar kringom meg der eg vankar, eg høyrer deg når mitt hjarta bankar. Du støtt meg fylgjer på ferdi mi, som sku ggen gjeng etter soli si.

Når nokon kjem og i klinka rykkjer, d'er du som kjem inn til meg, eg tykkjer; eg sprett frå stolen og vil meg te, men snart eg sig atter en de ned.
Når vinden lint uti lauvet ruslar, eg trur d'er deg som gjeng der og tuslar; når somt der borte eg ser seg snu, eg kvekk og trur det må vera du.

I kvar som gjeng og som rid og køyrer, d'er deg eg ser; deg i alt eg høyrer: i song og fløyte og felelåt, men en då best i min eigen gråt.

A asmund Olavsson Vinje 